\title{
Opposition to Antiracism Laws Across Swiss Municipalities: A Multilevel Analysis
}

\author{
Oriane Sarrasin
}

University of Lausanne

Eva G. T. Green

University of Lausanne

\author{
Nicole Fasel \\ University of Lausanne
}

\section{Oliver Christ}

Philipps-University Marburg, Germany

\section{Christian Staerklé}

University of Lausanne

\author{
Alain Clémence \\ University of Lausanne
}

Public opposition to antiracism laws-an expression of prejudice toward immigrants-is widespread in Switzerland as well as in other European countries. Using data from the European Social Survey $2002(\mathrm{~N}=1,711)$, the present study examined across Swiss municipalities individual and contextual predictors of opposition to such laws and of two well-established antecedents of prejudice: perceived threat and intergroup contact. The study extends multilevel research on immigration attitudes by investigating the role of the ideological climate prevailing in municipalities (conservative vs. progressive), in addition to structural features of municipalities. Controlling for individual-level determinants, stronger opposition to antiracism laws was found in more conservative municipalities, while the proportion of immigrants was positively related to intergroup contact. Furthermore, in conservative municipalities with a low proportion of immigrants, fewer intergroup contacts were reported. In line with prior research, intergroup contact decreased prejudiced policy stances through a reduction of perceived threat. Overall, this study highlights the need to include normative and ideological features of local contexts in the analysis of public reactions toward immigrants.

KEY WORDS: immigration, intergroup contact, perceived threat, ideological climate, multilevel, Switzerland 
Xenophobia and racism are major challenges for contemporary multicultural societies in Europe and elsewhere. Despite the progress achieved in drafting legislation prohibiting racism and discrimination on a national and an international (e.g., EU) level, for it to be efficient widespread public support is required. Indeed, opposition to laws prohibiting racism is one manifestation of prejudice toward immigrants. A growing body of research has employed a multilevel approach to demonstrate that prejudice and its antecedents-perceived threat and intergroup contact-are simultaneously affected by individual factors and by the social, economic, and political characteristics of the context in which individuals live. The current study is guided by this approach in its analysis of individual and contextual antecedents of opposition to antiracism laws across Swiss municipalities.

While effects of country characteristics on prejudice toward immigrants have been amply examined in a European context (e.g., Green, 2009; Quillian, 1995; Scheepers, Gijsberts, \& Coenders, 2002; Semyonov, Raijman, \& Gorodzeisky, 2006; Sides \& Citrin, 2007), less is known about the contextual variation within countries on a regional or local level (for exceptions in Sweden, Hjerm, 2009; in Germany, Wagner, Christ, Pettigrew, Stellmacher, \& Wolf, 2006; in the Netherlands, Lubbers, Coenders, \& Scheepers, 2006; Schlueter \& Scheepers, 2010). Moreover, most research investigating contextual effects has focused on the impact of structural factors such as migration patterns or economic conditions, thereby neglecting the possible impact of normative expectations within their communities on immigration attitudes (see, however, Pettigrew, 1958). Indeed, the prevailing ideological climate within a given local context can either legitimize or condemn negative attitudes towards immigration and immigrants. While prior research has examined the impact of ideological climates on immigration attitudes across countries (e.g., Semyonov et al., 2006), research on the effects of progressive versus conservative climates within a country is lacking. The present study aims to fill this gap by exploring with European Social Survey (ESS) data the influence of both the structural and the ideological context on opposition to antiracism laws in Switzerland. More specifically, we simultaneously examine the role of proportion of immigrants and the ideological climate at the municipality level as contextual antecedents of opposition to antiracism laws and of its individual-level predictors, perceived threat and intergroup contact.

\section{Individual Antecedents of Prejudice: Perceived Threat and Intergroup Contact}

Research drawing on an intergroup threat approach has demonstrated that threatening perceptions of immigration fuel xenophobia and racism (Blalock, 1967; for an overview see Riek, Mania, \& Gaertner, 2006). "Intergroup threat occurs when one group's actions, beliefs, or characteristics challenge the goal attainment or well-being of another group" (Riek et al., 2006, p. 336). Perceived threat can pertain to material aspects (e.g., suspicion that immigrants take jobs away from citizens) as well as to symbolic aspects (e.g., fear that the national values and traditions are called into question by immigrants' beliefs and practices; e.g., Stephan \& Renfro, 2003; see also Sears \& Henry, 2003). Prejudice can thus be seen as an attempt of the national ingroup to maintain or even enhance its dominant position in society and consequently to decrease threat.

Research driven by intergroup contact theory (e.g., Allport, 1954; Brown \& Hewstone, 2005; Pettigrew, 1998), in turn, has shown that interpersonal contacts through face-to-face interactions with outgroup members decrease prejudice. Allport (1954) originally argued that the beneficial effect of intergroup contact would occur only when certain conditions are met (i.e., equal intergroup status, common goals, intergroup cooperation, and institutional support). To the extent that immigrants frequently have lower social status than national citizens, fulfilling the condition of equality can be unrealistic in encounters between immigrants and host majority members. The recent meta-analysis of Pettigrew and Tropp (2006), however, showed that the conditions suggested by Allport increase the positive effects of contact but are not necessary for them to occur. Indeed, intergroup contact has been repeatedly proved effective in reducing xenophobia. Although intergroup contact also concerns 
relations with immigrant neighbours and colleagues, friendship with immigrants is a particularly effective way of reducing prejudice (e.g., Pettigrew, 1997; Turner, Hewstone, Voci, Paolini, \& Christ, 2007). Friendship is a high-quality, positive form of contact resulting in interpersonal attraction. In addition to quality of contact, reflected in agreeable friendships, quantity of contact (i.e., the number of friends and the frequency of contact) plays a role in reducing prejudice (Allport, 1954; Islam \& Hewstone, 1993). In our study, we simultaneously assess the quality and quantity of contact with a measure of number of intergroup friendships and expect that a greater number of intergroup friendships should contribute to the reduction of negative immigration attitudes.

Different affective processes explain why positive and pleasant contacts through intergroup friendships reduce prejudice. First, self-disclosure of personal and intimate information has been shown to mediate the relationship between contact and intergroup attitudes (Miller, 2002; Turner, Hewstone, \& Voci, 2007). Second, friendships with outgroup members decrease fear toward these groups (intergroup anxiety or perceived threat: Islam \& Hewstone, 1993, Semyonov \& Glikman, 2009; for a meta-analysis see Pettigrew \& Tropp, 2006). For example, in a study on intergroup relations within neighborhoods in Northern Ireland, positive contact with immigrants reduced offensive action tendencies, a relationship mediated by a decrease in both perceived safety threat and symbolic threat (Schmid, Tausch, Hewstone, Hughes, \& Cairns, 2008). The current study also examines such a mediation pattern: we expect quantity of friendships with immigrants to decrease opposition to antiracism laws through a reduction of perceived threat related to immigrants.

This mediation pattern should occur even after accounting for other well-documented individual background features of prejudice (for a review, see Ceobanu \& Escandell, 2010). For instance, citizens with a low socioeconomic status are more likely than high-status citizens to be in competition for the same jobs or housing as immigrants. It is therefore likely that members of low-status categories experience immigrants as more threatening than others and may thus be more inclined to be prejudiced (Scheepers et al., 2002). Age is another factor: Older people often hold more conservative worldviews than younger people (Cornelis, Van Hiel, Roets, \& Kossowska, 2009) and thus have more negative reactions towards immigrants. For similar reasons, though less consistently, men hold stricter immigration attitudes than women. Finally, foreign-born citizens often express more positive attitudes toward immigrants than citizens born in the country (e.g., Dandy \& Pe-Pua, 2010; Masso, 2009) because of higher probability of sharing common ties with immigrants (e.g., Espenshade \& Calhoun, 1993).

\section{Proportion of Immigrants and Reactions towards Immigrants}

Let us now turn to the contextual factors underlying prejudice. The proportion of immigrants in a given territory (country, region, neighborhood) is one of the most studied contextual antecedents of immigration attitudes. Two opposite predictions have received support regarding the proportion of immigrants. On the one hand, threat theorists (e.g., Blalock, 1967) have demonstrated that a strong presence of immigrants in a country or a region increases perceived threat because immigrants are seen as competing with nationals for the same jobs, housing, and other scarce resources (e.g., McLaren, 2003; Schneider, 2008) which further enhances negative attitudes toward immigrants (e.g., Quillian, 1995; Scheepers et al., 2002; Semyonov et al., 2006). On the other hand, extensions of intergroup contact theory have established that living in contexts with a high proportion of immigrants allows for more opportunities for contact through intergroup friendships, which decreases perceived threat and prejudice (Wagner et al., 2006; see also Schlueter \& Scheepers, 2010; Semyonov \& Glikman, 2009; Wagner, van Dick, Pettigrew, \& Christ, 2003).

The size of the contextual unit under study is one explanation put forward to understand such contrasting effects of immigrant presence. Oliver and Wong (2003) found that interethnic diversity was linked to lower perceived threat and prejudice at the neighborhood level, while it was related 
to higher levels at the city ("metropolitan") level. In the same vein, Wagner et al. (2006) suggested that when the contextual unit is large, the proportion of immigrants can become a political topic emphasizing threat and thus getting media attention, while in smaller contextual units of analysis (e.g., municipalities), positive intergroup contact effects are more likely to occur with a greater proportion of immigrants. It is plausible that natives have more contact with immigrants at the proximal level because "individuals negotiate their everyday relations" (Schmid et al., 2008, p. 59) through face-to-face contacts with people that are geographically close. These assumptions were corroborated in a recent cross-national study with ESS data (Semyonov \& Glikman, 2009) demonstrating that the likelihood to have immigrant friends was higher in multiethnic neighborhoods than in homogeneous all-European neighborhoods (note however that perceived threat related to immigrants was lower in mixed neighborhoods than in all-European and in mainly ethnic neighborhoods). The country-level proportion of immigrants, in turn, did not increase positive intergroup contact. Thus, in line with contact theory, the higher proportion of immigrants in Swiss municipalities is expected to increase intergroup contact opportunities and then, through a higher number of friendships with immigrants, to decrease perceived threat and opposition to antiracism laws.

\section{Conservative Ideological Climates and Immigration Attitudes}

In multilevel survey research, conservative ideologies have been up to now mainly conceptualized on the individual level with the respondents' political orientation, typically gauged through a left-right continuum (e.g., McLaren, 2003; Scheepers et al., 2002; Sides \& Citrin, 2007; Thorisdottir, Jost, Liviatan, \& Shrout, 2007; see however Davidov, Meuleman, Billiet, \& Schmidt, 2008). Conservative, right-wing ideologies have, for example, been related to higher levels of perceived threat and stronger anti-immigrant attitudes (for an overview see Esses, Jackson, Dovidio, \& Hodson, 2005). This is expected in the current research too.

However, individuals are necessarily embedded in a local political culture made up by norms, beliefs, and values widely shared by the members of a given community. In the present study, we refer to this normative context as the ideological climate that can be more or less conservative. A social representations approach which relates individual attitudes to wider societal processes (see Moscovici, 2000) allows conceptualizing the role of ideological climates in the construction of immigration attitudes (see Chryssochoou, 2004). According to this approach, ideological climates shape the way people think about unfamiliar or threatening social objects such as immigrants (Philogène \& Deaux, 2001). Such a climate of shared ideological beliefs is made up by normative rules and expectations (Elcheroth, Doise, \& Reicher, 2011; Lorenzi-Cioldi \& Clémence, 2001; Spini $\&$ Doise, 2005), which encourage and justify social practices and attitudes consistent with group norms (Staerklé, 2009; Staerklé, Clémence, \& Spini, 2011). However, even though a large majority of community members may be aware of dominant ideological representations, they are not necessarily consensual, as individuals may endorse or reject these normative ideologies (Clémence, 2001; Doise, Clémence, \& Lorenzi-Cioldi, 1993).

Conservative and progressive (or liberal) ideological climates differ on two core dimensions: resisting versus advocating social change and accepting versus rejecting inequalities (e.g., Jost, Glaser, Kruglanski, \& Sulloway, 2003). Moreover, in Switzerland and elsewhere, the cultural dimension of inclusiveness and exclusiveness increasingly structures ideologies (Bornschier, 2010). Ideological climates thus have a political function as they can bolster the power of dominant groups which embody the prevailing ideology (Joffe \& Staerklé, 2007). A conservative climate is therefore likely to provide justification for values and ideologies as well as the social policies that consolidate the dominant position of the national majority in the societal hierarchy (see also Bar-Tal, 2000; Jost, Ledgerwood, \& Hardin, 2008; Sidanius \& Pratto, 1999). Progressive climates, in turn, should 
promote values and ideologies attenuating differences between dominant and subordinate groups. These climates can be considered as contextual features in a multilevel design (see van de Vijver, van Hemert, \& Poortinga, 2008).

The empirical study of the impact of conservative climates on political attitudes is not new. Throughout Europe, though immigration issues cut across traditional party alignments, party affiliations continue to define stances toward immigration (e.g., Lahav, 1997). The handful of multilevel studies which investigated ideologies on the contextual level used the presence of radical right-wing parties across countries as indicators of a conservative climate. These studies linked a strong presence of such parties, over and above individuals' political orientation, to antiforeigner sentiment across European countries (Semyonov, Raijman, \& Gorodzeisky, 2006, 2007; Wilkes, Guppy, \& Farris, 2007). In another study, the relationship between a restrictive political climate regarding immigration (assessed with the positioning of political parties) and extreme right-wing voting in European countries was in fact due to favorable party characteristics such as charismatic leaders and well-organized parties (Lubbers, Gijsberts, \& Scheepers, 2002). Across European countries, public opinion on immigration coincides with positioning of the political elites (Lahav, 1997) and is reflected in EU policy developments on immigration and asylum (e.g., Lahav, 2004). This observation suggests a circular relationship between public opinion and political programs: citizens' opinions are informed by agendas of national parties which in turn rely on shared ideological beliefs of the public in order to mobilize their constituencies around a negative definition of immigrants.

We extend prior research by studying the role of ideological climates in a within-country context and examine the extent to which locally shared ideological climates shape citizens' reactions toward immigration. In a study on Swiss municipalities-albeit not examining individuals within municipalities-Helbling (2009) found lower naturalization rates of immigrants in municipalities with a strong presence of a radical right-wing party (SVP-Swiss People's Party), whereas economic factors had no impact on naturalization rates. To the extent that a strong presence of radical right-wing political parties reflects prevailing conservative ideologies, this research provides preliminary support for the idea that immigration attitudes are affected by shared ideological climates. However, using political parties as a proxy for widespread ideologies has caveats, especially in cross-national analyses. First, right-wing parties in different countries may not promote identical core ideologies, thus hampering cross-national comparisons. Indeed, in a study by Wilkes et al. (2007), only the prevalence of right-wing parties with a cultural racist agenda (i.e., with a discourse based on cultural rather than biological differences) was related to antiforeigner attitudes. Second, the examination of the effects of the average political climate of a nation masks potentially important variations within a country. Third, some political parties are regional rather than national, which also makes within-country comparisons difficult. Compared to multination analyses, a within-country analysis keeps the national institutional and legislative context constant across the contextual units under examination. These units are therefore more easily comparable than countries. It can therefore be excluded that observed attitudinal differences between contexts are due to nationally defined institutional factors. Hence, attitudinal comparisons between local contexts seem less prone to speculative explanations than country-level comparisons.

Consequently, in the present study we assess progressive and conservative ideological climates across Swiss municipalities based on political stances of the voting population. As Switzerland is a direct democracy, citizens vote several times a year on various topics, allowing one to grasp prevailing ideologies in municipalities. In our analyses, we use an indicator of municipality-level ideological climate based on the actual outcomes of national referenda over a period of 10 years. Due to the variety of referendum topics (e.g., foreign policy, social liberalization, and reforms in political institutions; Hermann, 2006) and the large amount of referendum data, ideological differentiation of municipalities is greater compared to the use of election results (Leuthold, Hermann, \& Fabrikant, 
2007). This allows placing municipalities on a continuum of progressive versus conservative climate and then exploring the impact of the ideological climate on opposition to antiracism laws and its antecedents.

We expect that the normative context of a conservative municipality fuels and justifies negative reactions toward immigrants (i.e., less intergroup contact, greater threat perceptions, and stronger opposition to antiracism laws). Conservative climates are thus likely to mobilize anti-immigrant attitudes (see Sniderman, Hagendoorn, \& Prior, 2004): through a presumed process of normative compliance, independently of their political orientation or their social status, residents of conservative contexts should express more negative reactions towards immigrants than residents of progressive municipalities. On the contrary, a progressive climate should reduce the normative support for xenophobic stances and thus decrease negative reactions towards immigrants (Falomir-Pichastor, Muñoz-Rojas, Invernizzi, \& Mugny, 2004). However, because progressive ideologies not only promote equality and inclusiveness but also tolerance and individual freedom (Jost, Krochik, Gaucher, \& Hennes, 2009; for Switzerland, see Bornschier, 2010), there should be less conformity pressure and more leeway for diverging personal attitudes. Thus, paradoxically, the relationship individual-level predictors of prejudice (e.g., right-wing political positions) and negative reactions towards immigrants (threatening immigrant perceptions, absence of positive contacts with immigrants, and opposition to antiracism laws) should be stronger in progressive rather than conservative climates. Finally, we also expect the normative impact of an ideological climate to depend on the intensity of the relationship between the national majority group and immigrant outgroups within a community. Hence, ideological climate and proportion of immigrants should have joint or interactive effects. Fewer intergroup friendships, higher level of perceived threat, and more opposition to antiracism laws are therefore expected in conservative municipalities with low opportunities of intergroup contact, that is, when the proportion of immigrants is low.

\section{Current Study}

We employed the Swiss subsample from the ESS 2002 immigration module to examine the effects of immigrant presence and ideological climate across Swiss municipalities on the reported friendship contacts with immigrants, perceived threat related to immigrants, and opposition to antiracism laws.

The Swiss context. Switzerland is a multicultural country with over $20 \%$ of foreign residents (the highest immigrant resident population in Europe after Luxembourg) and four national languages (German, French, Italian, and Romansh) spoken in different regions. Immigration has been a hot topic in Swiss politics and media during this decade (e.g., Helbling, 2010; Nicolet \& Sciarini, 2006; Sciarini \& Tresch, 2009). While authorities have been urged to implement more comprehensive criminal and civil legislation prohibiting racism and discrimination (see European Commission against Racism and Intolerance ECRI, 2009), the content and existence of such legislation has been challenged, even by elected representatives such as the minister of justice and police who proposed in 2007 to cancel existing antiracism laws (see press release from the Federal Department of Justice and Police, 2007). As the ethnic minority population consists mainly of immigrants, it is timely to examine opposition to antiracism laws as an indicator of public opinion regarding immigration. Such opposition will be studied across a subset of the over 2000 Swiss municipalities. Because Switzerland is a decentralized federal state, political discussion and deliberation often takes place at the local level (e.g., Dardanelli, 2008; Horber-Papazian, 2007). Moreover, municipalities have executive power regarding several immigration policies. For example, naturalization decisions are made on the municipality level across the nation (e.g., Helbling, 2009), and in some cantons (e.g., Bern, Thurgau) municipalities have decided whether to grant voting rights to immigrants for local votes. 


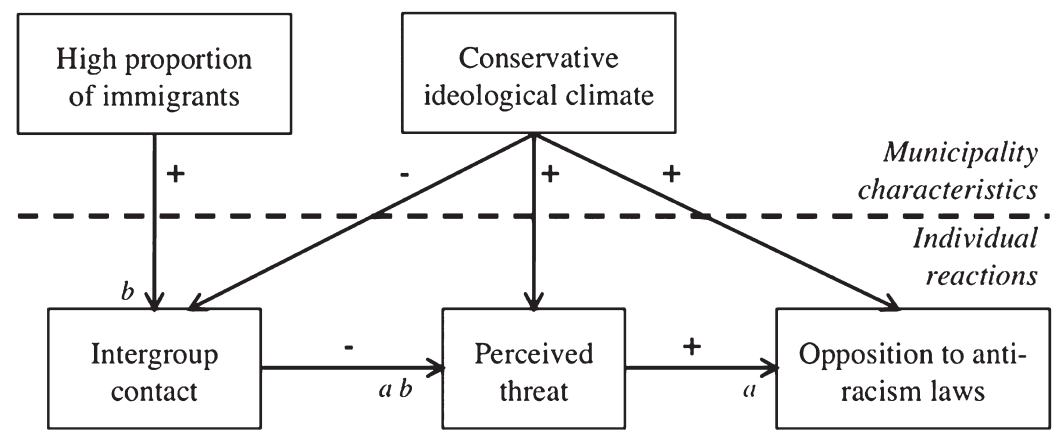

$a=$ indirect effect from intergroup contact to opposition to antiracism laws via perceived threat;

$b=$ indirect effect from proportion of immigrants to perceived threat through intergroup contact; see Indirect Paths in Results section.

Figure 1. Summary of predictions and indirect paths.

Predictions. The multilevel design of the study allows testing hypotheses simultaneously on the individual and the municipality level (Hox, 2010). Individuals are nested within municipalities. While each level of this nested structure is a distinct level of analysis, multilevel techniques enable their joint analysis. Figure 1 summarizes our predictions. On the individual level, we expect that, controlling for relevant background variables, intergroup contact decreases and perceived threat increases opposition to antiracism laws. Perceived threat is expected to mediate the impact of contact on immigration attitudes. On the contextual level, we hypothesize that a high proportion of immigrants within a municipality is related to more intergroup contact, which in turn should decrease perceived threat and opposition to antiracism laws. A conservative ideological climate is expected to decrease contact, while increasing perceived threat and heightening opposition to antiracism laws. In addition to the predictions depicted in Figure 1, ideological climate and proportion of immigrants may also interact such that the most negative reactions (i.e., less intergroup contact, high perceived threat, and opposition to laws) should be found in conservative municipalities with a low proportion of immigrants. Ideological climate may also moderate individual-level relations, evidenced by cross-level interactions: for instance, perceived threat may be more strongly related to opposition to antiracism laws in progressive rather than conservative municipalities as only people holding individual predispositions to prejudice toward immigrants may indeed express opposition. In conservative municipalities, however, the prevailing ideologies may lead to generalized compliance with opposition to antiracism laws independently of individual characteristics.

\section{Method}

\section{Sample}

Our initial sample consisted of 1,822 Swiss citizens. As comparing models requires equal sample sizes, participants from municipalities lacking contextual data were excluded, while missing data on individual-level variables were imputed (see below). ${ }^{1}$ The reduced sample contained no missing data $(N=1,711), 818$ male and 893 female respondents $(M=48.16$ years; $S D=17.56)$, with 1,313 participants from the German-speaking part and 398 from the French-speaking part (reflecting the percentages found in the overall population: in $2000,63.7 \%$ of the population have German and $20.4 \%$

${ }^{1}$ Analyses performed only with respondents who answered all questions $(N=1,270)$ yielded very similar results. 
Table 1. Complete Item Wording for Contact, Perceived Threat and Opposition to Antiracism Laws

\begin{tabular}{c} 
Do you have any friends who have come to live in Switzerland from another country? \\
\hline Perceived threat related to immigration \\
Average wages and salaries are generally brought down by people coming to live and work here (from \\
1 = agree strongly to $6=$ disagree strongly; reversed item) \\
People who come to live and work here generally harm the economic prospects of the poor more than the rich \\
(from $1=$ agree strongly to $6=$ disagree strongly; reversed item) \\
Would you say that people who come to live here generally take jobs away from workers in Switzerland, or \\
generally help to create new jobs? (from $0=$ take jobs away to $10=$ create new jobs; reversed item) \\
Most people who come to live here work and pay taxes. They also use health and welfare services. On \\
balance, do you think people who come here take out more than they put in or put in more than they take \\
out? (from $0=$ generally take out more to $10=$ generally put in more; reversed item) \\
Would you say it is generally bad or good for Switzerland's economy that people come to live here from \\
other countries (from $0=$ good to $10=$ bad) \\
Would you say that Switzerland's cultural life is generally undermined or enriched by people coming to live \\
here from other countries? (from $0=$ undermined to $10=$ enriched; reversed item)
\end{tabular}

Opposition to antiracism laws: How good or bad are each of these things for a country? (from $0=$ extremely bad to

$10=$ extremely good; reversed item)

A law against racial or ethnic discrimination in the workplace

A law against promoting racial or ethnic hatred

French as first language; see Federal Statistical Office: FSO, 2010a). Respondents came from 176 municipalities ( 2 to 78 respondents per municipality, $M=9.72, S D=7.54 ; 17$ municipalities had less than five respondents). ${ }^{2}$ The other official linguistic groups, including $4.3 \%$ of Swiss Italians and 0.6 $\%$ of Romansh, were excluded from the present study because of a low (Italian, $N=60$ ) or inexistent (Romansh) number of respondents.

\section{Reactions toward Immigrants}

Contact with immigrants was assessed with the reported number of friends who have come to live in Switzerland from another country $(1=$ no, none at all, $26.28 \%$ of respondents; $2=$ yes, a few, $45.45 \% ; 3=$ yes, several, $28.27 \%$; recoded from 0 to 2$){ }^{3}$ Perceived threat related to immigrants items was measured with six statements $(\alpha=.75)$, while Opposition to antiracism laws score was made up of two items $(\alpha=.79)$. The exact wording for all items is presented in Table 1.

Missing data $(0.33 \%$ for contact; $0.29 \%$ for perceived threat and $4.03 \%$ for opposition to antiracism laws) were imputed using multiple regression (with gender, age, education, income,

\footnotetext{
${ }^{2}$ At the outset of the study, different levels of contextual variables were considered (e.g., canton, district) to ensure a methodologically adequate ratio between level-1 and level-2 units (Hox, 2010). Though multilevel analyses can legitimately be performed with a low number of respondents per contextual unit (Gelman \& Hill, 2007; Maas \& Hox, 2005), we wanted to ensure that some large municipalities did not influence our results too heavily. In additional analyses, municipalities within the same canton were grouped as a function of similar contextual characteristics (located within the same quartile of percentage of immigrants and conservative climate; see section on Contextual predictors below; 87 municipality aggregations, $M=19$ respondents per municipality aggregation). The results with the matched municipality groups and those excluding municipality groups with less than eight respondents were almost identical to findings presented in this article. However, aggregating municipalities that are not directly neighboring (despite being in the same canton) did not correspond to our initial theoretical assumption that people are influenced by shared ideologies and representations in their everyday relationships within local communities. Thus, only results with unaggregated municipalities as contextual units are presented in the Results section.

${ }^{3}$ Despite having only three categories, the contact variable was treated as continuous (see also McLaren, 2003; Schlueter \& Wagner, 2008, for this solution with ESS 2002 data) for two reasons: First, we were interested in the impact of quantity of positive contact. Second, three-quarters of Swiss respondents reported having at least a few friends among immigrants (e.g., Semyonov \& Glikman, 2009), which makes investigating the odds of having or not having friends among immigrants uninformative.
} 
political orientation, and linguistic region as predictors; uvis command in Stata, Royston, 2005). To enable comparisons and the creation of scores, the items of perceived threat and opposition to antiracism laws were linearly transformed to scales between 0 and 100, such that high scores indicate high level of perceived threat $(M=50.10, S D=14.53)$ or strong opposition to antiracism laws $(M=36.84, S D=27.03)$.

Given the conceptual closeness of perceiving an outgroup as a threat and holding prejudiced attitudes towards this outgroup (e.g., Sears \& Henry, 2003), multilevel confirmatory factor analyses were performed prior to our main analyses to verify that the two concepts were empirically distinct. A model grouping items of perceived threat and opposition to antiracism laws on one factor on both individual and municipality levels, $\chi^{2}(40)=1964.23, p<.001 ; \mathrm{CFI}=.39$, RMSEA $=$ $.16, \quad \mathrm{SRMR}_{\text {individual }}=.11, \quad \mathrm{SRMR}_{\text {municipality }}=.16, \quad$ showed a significantly worse fit than a two-factor model, $\chi^{2}(38)=264.66, p<.001 ; \mathrm{CFI}=.93, \quad \mathrm{RMSEA}=.06, \quad \mathrm{SRMR}_{\text {individual }}=.04$, $\mathrm{SRMR}_{\text {municipality }}=.12 ; \Delta \chi^{2}(2)=1699.57, p<.001$, confirming that perceived threat and opposition to antiracism laws were separate constructs. Model fits further improved when residuals of two threat items were allowed to correlate (i.e., "Wages are brought down by immigrants" and "Immigrants harm the economic prospect"; $\chi^{2}(37)=81.82, p<.001 ; \mathrm{CFI}=.99, \quad \mathrm{RMSEA}=.03, \quad \mathrm{SRMR}_{\text {individual }}=$ $\left..02, \mathrm{SRMR}_{\text {municipality }}=.13\right)$. In this last model the relative chi-square was also adequate $\left(\chi^{2} / \mathrm{df}=2.24\right.$; Wheaton, Muthén, Alwin, \& Summers, 1977).

\section{Individual Background Variables}

In addition to participant sex $(0=$ male; $1=$ female) and age, education (number of years of full-time education; $M=10.73, S D=3.29$ ), monthly net household income (from $1=$ less than 230 francs [approx. $150 €$ ] to $12=$ more than 15,000 francs [approx. 10,000 €]) and political orientation $(0=$ far left to $10=$ far right $)$, and place of birth $(0=$ born outside Switzerland, $N=157 ; 1=$ born in Switzerland, $N=1,554)$ were included as control variables. ${ }^{4}$ Household income contained $21.27 \%$ and political orientation $6.95 \%$ missing values. To avoid a substantial decrease of sample size, the missing values of income and political orientation were replaced through multiple regression (with age, gender, education, and linguistic region as predictors; uvis command in Stata). Respondents were on average in the middle of the political orientation continuum $(M=4.90, S D=1.85)$. The mean household income value was $8.62(S D=2.01)$, which roughly corresponds to the mean net income of Swiss households 2002 (i.e., 6594 francs; FSO, 2010b). Correlations between individual background variables did not exceed $r=+/-.20$, with the exception of age and income $(r=-.29){ }^{5}$ All continuous individual-level predictors were standardized.

\section{Contextual Predictors}

Percentage of immigrants (source: FSO, 2010c) in municipalities in 2002 ranged between $1.03 \%$ and $52.27 \%(M=17.70, S D=9.83$; on the national level, $20.17 \%$ of residents did not have Swiss citizenship in 2002). A global conservative climate score of municipalities was created from a data set on referendum results of all Swiss municipalities from 1995 to 2006 (Hermann, 2006). The referendum results of municipalities were organized in nine thematic scores. In a municipality-level

\footnotetext{
${ }^{4}$ Given the existing urban-rural cleavage in political stances in Switzerland, preliminary analyses on both levels were performed with place of residence as a control variable. Including either a five-category variable (big city, suburbs, town, country village, and farm or home in countryside) on the individual level or a dichotomous variable (urban vs. rural) on the municipality level did not yield significant effects and did not affect the overall results.

${ }^{5}$ Further examination showed that age was negatively correlated with income $(r=-.31, p<.001)$ only among respondents over 60 years old - most of whom were retired-while among respondents under 60 the relationship was not significant $(r=-.02, p=.43)$.
} 
exploratory factor analysis performed on the nine thematic scores, four loaded on the same factor: referendum results on stricter immigration policies (consisting of six referendums; e.g., restriction of proportion of immigrants), social liberalization (reversed; consisting of 11 referendums; e.g., acceptance of abortion), open foreign policy (reversed; consisting of six referendums; e.g., adhesion to the European Union) and changes and reforms in government and parliament (reversed: consisting of four referendums; e.g., justice reform). The score of stricter immigration policies was omitted because of its conceptual closeness with the dependent variables. The three remaining thematic scores were averaged into a score of conservative climate for each municipality. ${ }^{6}$ Hence conservative climate is defined with shared political stances on a wide range of issues over time. In the employed sample of municipalities, scores ranged from -23.57 (most tolerant) to 16.22 (most conservative) with a mean of 1.29 ( $S D=8.33$; 0 representing the overall Swiss mean).

Differences between linguistic regions are a potentially important factor in analyses of immigration attitudes in Switzerland. Not only are data collected in different languages, which may lead to methodological biases (e.g., Billiet, 2003), but stricter immigration stances are usually found in the German-speaking region, compared to the French-speaking region (e.g., Kriesi, Wernli, Sciarini, \& Gianni, 1996; Trechsel, 2007). We first checked for measurement invariance (e.g., Steenkamp \& Baumgartner, 1998) by performing multigroup confirmatory analyses (in addition accounting for the multilevel structure of the data where individuals are nested in municipalities). That is, we tested whether the factor structure of scores and item loadings were similar across regions. Results showed that both perceived threat and opposition to antiracism laws had the same factor structure and equal item intercepts across the two linguistic groups, $\chi^{2}(50)=311.01, p<.001 ; \mathrm{CFI}=.91$, RMSEA $=.08$, $\mathrm{SRMR}=.06$, allowing us to proceed with the main analyses. ${ }^{7}$ In addition, we found differences in the contextual variables used in the present study with a stronger presence of immigrants in the French-speaking $(M=23.95 \%, S D=12.30)$ than in the German-speaking region $(M=15.91 \%$, $S D=8.21)$ and a more conservative climate in the German-speaking $(M=3.35, S D=7.25)$ than in the French-speaking region $(M=-5.38, S D=6.02)$. As the focus of the current study is not the examination of the cleavage between linguistic groups, all contextual variables were regressed separately on the dichotomous linguistic region $(0=$ German and $1=$ French $)$ variable in order to avoid confounding effects. The standardized residuals were used as predictors in the main analyses (e.g., Kuhn \& Holling, 2009; Luo, Rindfleisch, \& Tse, 2007). The inclusion of linguistic region with the raw contextual scores in the models did not alter the findings (see subsection of additional analyses in the Results section).

Residual scores of proportion of immigrants and conservative climate were moderately correlated, $r(176)=-.37, p<.001$. All analyses were performed with outlier values $(M+/-3 * \mathrm{SD})$ replaced by the cut-off value: this replacement was applied to one municipality for percentage of immigrants and to another one for conservative climate.

\section{Results}

Multilevel regression analyses were performed with Mplus 5.1. Multilevel modelling allows simultaneously testing the part of the variation in individual-level variables (i.e., contact, perceived threat, and opposition to antiracism laws) which are explained by municipality-level effects (conservative climate and $\%$ of immigrants) and the part explained by individual-level effects (e.g., Hox,

\footnotetext{
${ }^{6}$ To ensure that results were not due to the impact of one particular thematic score, additional analyses were performed with each score separately. The separate thematic scores yielded similar results to the overall ideological climate score. These additional analyses are available upon request from the authors.

${ }^{7}$ Model fits were further improved when the intercepts of four threat items were allowed to vary and when errors of two threat items (same items as for entire sample, see above) were allowed to correlate: $\chi^{2}(44)=113.84, p<.001 ; \mathrm{CFI}=.98$, $\mathrm{RMSEA}=.04, \mathrm{SRMR}=.04$.
} 
2010). On the individual level, we focused on the mediation pattern from contact to opposition to antiracism laws through a decrease in perceived threat. On the contextual level, we first examined whether conservative climate and proportion of immigrants had direct effects on contact, perceived threat, and opposition to antiracism laws and then assessed a set of indirect effects. Finally, additional analyses are presented to gain further support for the revealed result patterns.

\section{Multilevel Model Building}

Models were built step by step separately for intergroup contact, perceived threat, and opposition to antiracism laws. These variables were regressed upon individual-level predictors (sex, education, age, household income, right-wing political orientation, place of birth; with intergroup contact for perceived threat as outcome variable; with intergroup contact and perceived threat for opposition to antiracism laws as outcome variable) and upon municipality-level predictors (conservative climate, $\%$ of immigrants, conservative climate $\times \%$ of immigrants). Improvement of goodness-of-fit statistics (i.e., model deviance provided by $-2 * \log l i k e l i h o o d$ ) and explained variance for all models are presented in Table 2. For the three dependent variables, intercept-only models (i.e., with no predictors; Models 0) were tested to estimate variance on both individual (level 1) and contextual levels (level 2). All dependent variables had a significant amount of variance at the municipality level, that is, a substantial part of the overall variance was due to the clustered structure of the data (i.e., living in a certain municipality): Intra-class Correlations (ICC) for contact was .091, for perceived threat .105, for opposition to antiracism laws .060. Neglecting the hierarchical structure and the error terms at the municipality level in subsequent analyses would underestimate the standard errors of the dependent variables and may result in erroneous confirmation of hypotheses (e.g., Hox, 2010; Kreft \& de Leeuw, 1998). Next, individual-level antecedents were included in Model 1 for each dependent variable. In all cases the model deviance decreased significantly (see Table 2).

Table 2. Changes in Model Fit and Explained Variance in Multilevel Models for Contact, Perceived Threat and Opposition to Antiracism Laws

\begin{tabular}{|c|c|c|c|c|c|}
\hline & Model 0 & Model 1a & Model 1b & Model 2 & Model 3 \\
\hline & $\begin{array}{c}\text { Intercept } \\
\text { only }\end{array}$ & $\begin{array}{l}\text { Individual } \\
\text { predictors, } \\
\text { background } \\
\text { variables }\end{array}$ & $\begin{array}{c}\text { Individual } \\
\text { predictors, }+ \text { contact } \\
\text { and threat }\end{array}$ & $\begin{array}{l}\text { Contextual } \\
\text { predictors, } \\
\text { main effects }\end{array}$ & $\begin{array}{l}\text { Contextual } \\
\text { predictors, } \\
\text { interaction }\end{array}$ \\
\hline \multicolumn{6}{|l|}{ Contact } \\
\hline$\Delta$ Deviance $^{\mathrm{a}}(\Delta \mathrm{df})$ & $3,762.28$ & $191.73 * * *(6)$ & & $18.87 * * *(2)$ & $4.21 *(1)$ \\
\hline$\%$ explained variance: individual level & 0 & $9.31 \%$ & & $9.51 \%$ & $9.51 \%$ \\
\hline$\%$ explained variance: contextual level & 0 & $36.00 \%$ & & $50.00 \%$ & $54.00 \%$ \\
\hline \multicolumn{6}{|l|}{ Perceived threat } \\
\hline$\Delta$ Deviance $(\Delta \mathrm{df})$ & $13,939.44(0)$ & $140.66 * * *(6)$ & $67.94 * * *(1)$ & $0.84(2)$ & $2.78 \dagger(1)$ \\
\hline$\%$ explained variance: individual level & 0 & $6.71 \%$ & $9.64 \%$ & $9.65 \%$ & $9.67 \%$ \\
\hline$\%$ explained variance: contextual level & 0 & $28.52 \%$ & $40.74 \%$ & $42.92 \%$ & $45.13 \%$ \\
\hline \multicolumn{6}{|l|}{ Opposition to antiracism laws } \\
\hline$\Delta$ Deviance $(\Delta \mathrm{df})$ & $16,109.64(0)$ & $142.24 * * *(6)$ & $50.86 * * *(2)$ & $8.40 *(2)$ & $0.26(1)$ \\
\hline$\%$ explained variance: individual level & 0 & $7.23 \%$ & $9.34 \%$ & $9.33 \%$ & $9.34 \%$ \\
\hline$\%$ explained variance: contextual level & 0 & $27.56 \%$ & $43.41 \%$ & $53.40 \%$ & $53.47 \%$ \\
\hline
\end{tabular}

Note. Intercepts for Model 0 are: $1.00(0.03)^{* * *}$ for contact; $50.40(0.50)^{* * *}$ for perceived threat; $37.32(0.84)^{* * *}$ for opposition to antiracism laws.

a $-2 *$ Loglikelihood

$\dagger p<.10 . * p<.05 . * * p<.01$. *** $p<.001$. 
Contextual predictors (conservative climate and percent of immigrants) were entered in Model 2 for each dependent variable. ${ }^{8}$ A significant contextual effect implies that the average score (by municipality) of contact, perceived threat, or opposition to antiracism laws is significantly related to a municipality characteristic. For contact and opposition to antiracism laws, the model deviance decreased significantly, meaning that a model with the two contextual predictors (i.e., Model 2) increases the contextual-level explained variance of these two dependent variables compared to a model without them (i.e., Model 1). This was not the case for perceived threat. The level-2 interaction between percentage of immigrants and conservative climate was entered in a next step (Model 3). The interaction improved the model only for contact and will thus only be examined further for this variable (the deviance change was marginally significant for perceived threat, but as the interaction was not significant Model 3 is not displayed). The inclusion of the interaction term in the models for perceived threat and opposition to antiracism laws did not modify the reported findings. All slope variances were fixed, as none of the relationships between individual-level predictors of interest and dependent variables were found to significantly vary across municipalities (i.e., no random slopes were found). Thus cross-level interactions were not tested. Results for Models 1, 2, and 3 (only for contact) are presented in Table 3.

\section{Individual-Level Effects}

First, relationships between intergroup contact, perceived threat, and opposition to antiracism laws were examined in Model 1. As expected, when accounting for all individual background variables, intergroup contact was related to lower levels of perceived threat $(b=-3.93, p<.001)$. In turn, the more respondents perceived immigrants as threatening, the more they expressed opposition to antiracism laws $(b=4.71, p<.001)$. Intergroup contact $(b=0.10, p=.92)$ was not significantly related to opposition to antiracism laws (this was also the case when perceived threat was omitted from the model, $b=-1.17, p=.23$ ).

Examination of the other individual-level predictors (see Model 1 for each dependent variable) revealed that in line with prior research, lower education levels and a right-wing political orientation were related to lower reported numbers of immigrant friends, greater perceived threat, and stronger opposition to antiracism laws. Moreover, older participants reported less contact and stronger opposition to antiracism laws. Men reported having more immigrant friends and marginally lower levels of perceived threat, while sex of respondent was unrelated to opposition to antiracism laws. Finally income and being born outside Switzerland were both associated with more intergroup contact, but unrelated to perceived threat and opposition to antiracism laws. Individual-level effects remained similar in Models 2 and 3 which included contextual predictors.

\section{Municipality-Level Effects}

While we expected proportion of immigrants to be related to more intergroup contact, thereby reducing opposition to antiracism laws through lower levels of threat, our predictions concerning the impact of conservative climate were more open. In a conservative climate, respondents should express more opposition to antiracism laws over and above the effects of individual-level antecedents, but the climate might also affect antecedents of opposition. Moreover, we hypothesized that the conjunction of a conservative climate and low proportion of immigrants could trigger particularly negative reactions toward immigrants (less contact, more perceived threat, more opposition to antiracism laws).

\footnotetext{
${ }^{8}$ In preliminary analyses, context-level predictors were entered in the model one-by-one revealing similar effects. When entered alone in the model, proportion of immigrants was marginally related to opposition to antiracism laws $(b=-1.28$, $p=.07)$. This effect no longer reached significance when the contextual predictors were entered together in the model.
} 


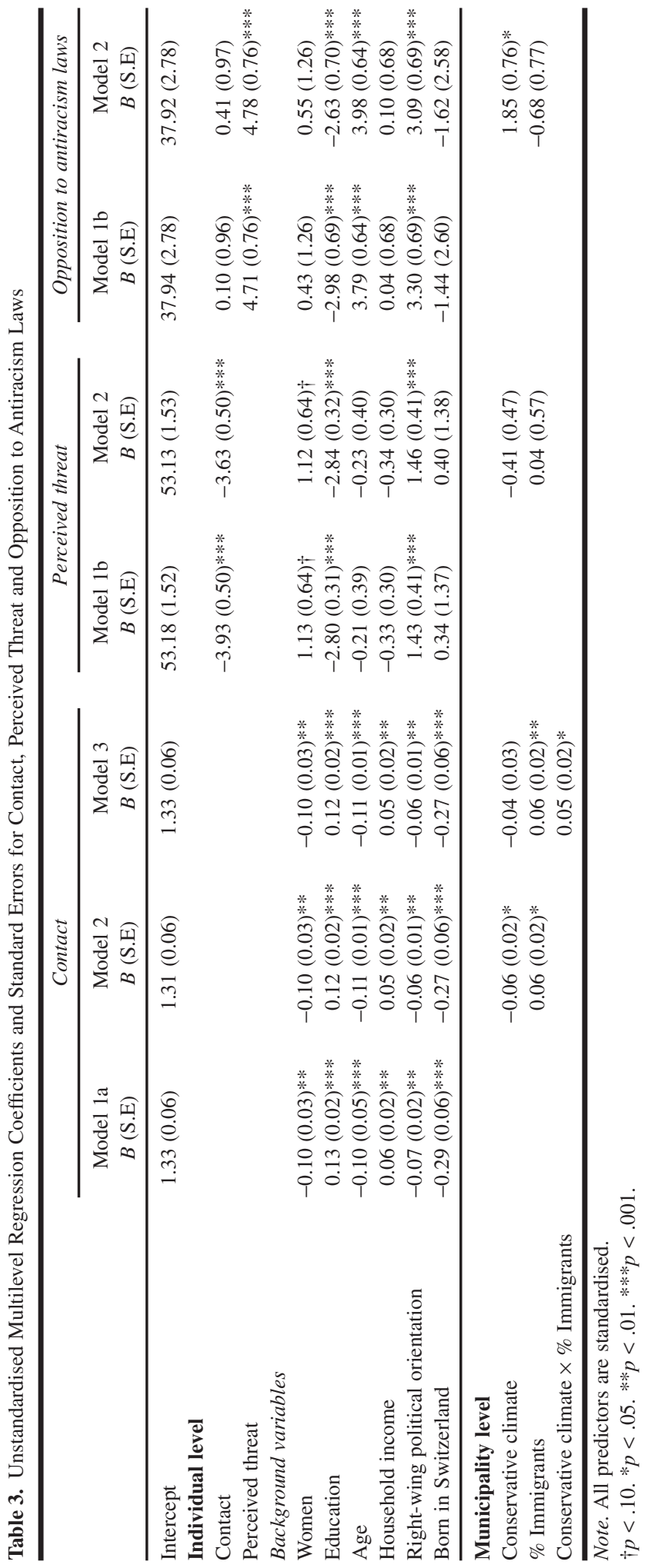




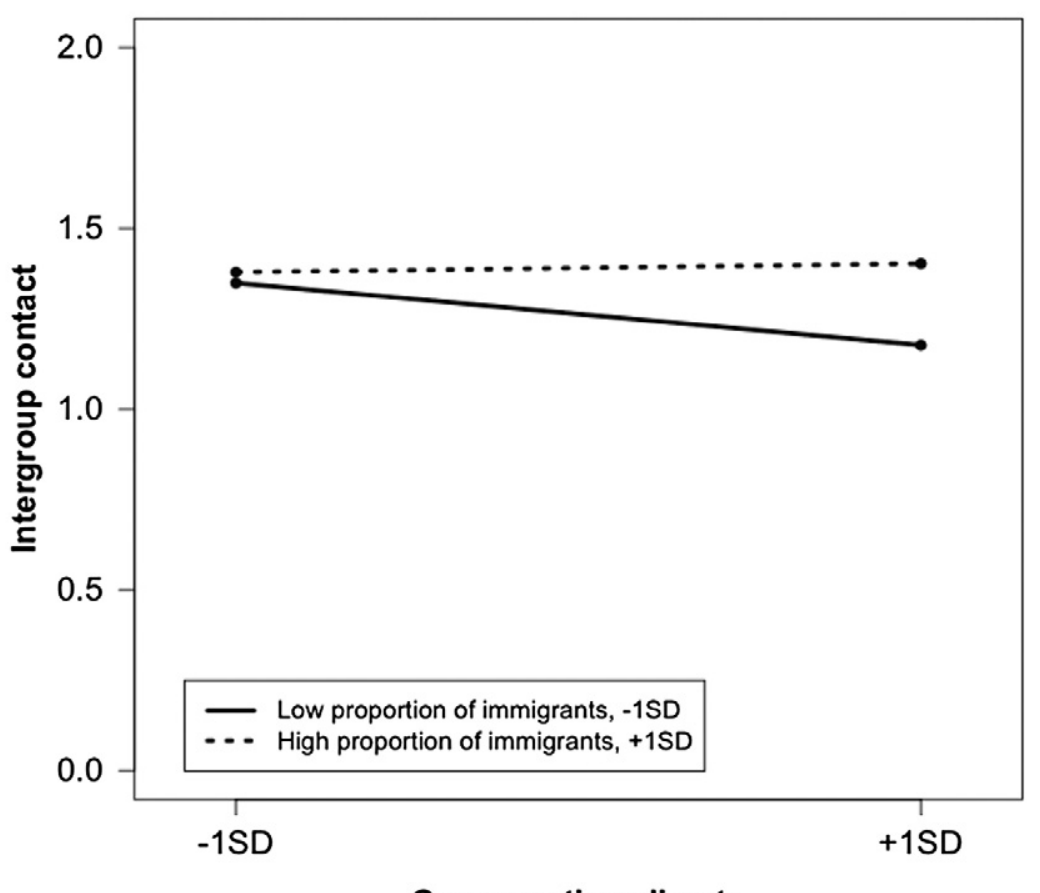

Conservative climate

Figure 2. Intergroup contact as a function of proportion of immigrants and conservative climate in a municipality.

Intergroup contact. Model 2 in Table 3 indicates that both conservative climate $(b=-0.06$, $p=.01)$ and proportion of immigrants $(b=0.06, p=.01)$ were significantly related to intergroup contact. While, as hypothesized, fewer friendships with immigrants were reported in conservative municipalities, this effect did not remain significant $(b=-0.04, p=.14)$ when the interaction term was entered in Model 3. Moreover, in line with the contact theory assumption that immigrant presence provides opportunities for contact, the higher the proportion of immigrants in a municipality, the more respondents reported having friends among immigrants. This effect was qualified by an interaction with conservative climate $(b=0.05, p=.02$; see Model 3). As shown in Figure 2, multilevel simple slope analyses (Preacher, Curran, \& Bauer, 2006) revealed that in municipalities with a high immigrant proportion $(M+1 S D)$, conservative climate did not affect the reported number of contacts with immigrants $(b=0.01, p=.76$ ). As expected, in municipalities with a low proportion of immigrants $(M-1 S D)$, the more conservative the climate, the less respondents reported friendships with immigrants $(b=-0.09, p<.001)$. The final model explained $54 \%$ of the contextual variance.

Perceived threat. Unexpectedly, neither conservative climate $(b=-0.41, p=.38)$ nor the percentage of immigrants $(b=0.04, p=.95)$ were related to perceived threat (Model 2). The majority of explained contextual variance was accounted for after the inclusion of individual predictors in Model 1 ( $41 \%$ out of $45 \%$ in the last model). Thus, the municipality-level variance of threat was mainly due to the different sociodemographic composition of municipalities.

Opposition to antiracism laws. Conservative climate was related to opposition to antiracism laws ( $b=1.85, p=.02$; see Model 2): opposition was higher in more conservative municipalities. It must be underscored that the effect of municipalities' conservative climate was found while controlling for contact, perceived threat, as well as political orientation and other individual-level 
background variables. That is, the conservative climate of municipalities increases opposition to antiracism laws over and above the sum of individual effects. The percentage of immigrants had no effect on opposition to antiracism laws $(b=-0.68, p=.38)$. Fifty-three percent of the contextual variance was explained.

\section{Indirect Paths}

Next, indirect effects (i.e., mediation patterns) were examined. When individual-level variables vary significantly across clusters, Mplus allows treating their group averages as latent variables on the municipality level (Lüdtke et al., 2008), thereby decomposing the variance into individual- and municipality-level variance. Indeed, Preacher, Zyphur, and Zhang (2010) advise separating level-1 variance (e.g., across individuals) from level-2 variance (e.g., across municipalities) when estimating indirect paths in multilevel models. Neglecting to do so may conflate estimates of indirect components, that is, a significant path on the individual level may in fact be due to a difference in municipality means. This procedure thus allows testing the indirect effects from contact to opposition to antiracism laws via perceived threat on both levels simultaneously (see path $a$ in Figure 1). As predicted, on the individual level, contact decreased opposition to antiracism laws through a reduction in perceived threat (indirect path $b=-1.06, p<.001 ; 95 \% \mathrm{CI}=-1.54,-0.59$ ). Hence, while contact did not directly relate to opposition to antiracism laws (as shown in the section of individuallevel effects), an indirect relation emerged. On the contextual level, this mediation pattern was marginally significant (indirect effect $b=-19.12, p=.09 ; 95 \% \mathrm{CI}=-40.89,2.66$ ).

Moreover, multilevel mediation allows investigating effects at different levels of analysis (e.g., Krull \& MacKinnon, 2001). In addition to direct effects of conservative climate and proportion of immigrants, we expected that these level-2 independent variables may also indirectly, through contact or perceived threat (level-1 mediators), affect later stages of the mediation pattern (i.e., threat or opposition to antiracism laws). Only the revealed main effect of proportion of immigrants on contact allowed such an examination (see path $b$ in Figure 1). When controlling for conservative climate, percentage of immigrants had a marginal effect on perceived threat through an increase of intergroup contact (indirect effect $b=0.06, p=.09 ; 95 \% \mathrm{CI}=-0.10,0.14$ ).

\section{Additional Analyses}

Before concluding on the effects of proportion of immigrants and conservative climate in municipalities, we controlled for other contextual features that may also shape reactions toward immigrants in Switzerland. Threat theories propose that competition between the national ingroup and immigrant outgroups, and consequently negative reactions toward immigrants, are greater under disadvantageous economic conditions (Green, 2009; Meuleman, 2010; Quillian, 1995; Wilkes \& Corrigall-Brown, 2011). We therefore accounted for socioeconomic conditions of municipalities ${ }^{9}$ : The inclusion of the socioeconomic status of municipalities in the model did not affect the aforementioned result patterns. Moreover, while the socioeconomic status was unrelated to perceived threat or opposition to antiracism laws, respondents reported more intergroup contact with immigrants in municipalities with a high socioeconomic status $(b=0.07, p=.008)$.

\footnotetext{
${ }^{9}$ We used a weighted average score of municipality socioeconomic status (FSO, 2010d, indices available from the 2000 census) based on net income, highest level of education achieved and position within a profession of all residents of a municipality (score ranged from 34.56 to $80.23, M=49.63, S D=7.69$; high scores indicate higher socioeconomic status of the municipality, 50 represents the mean score for Switzerland). While socioeconomic status of municipalities was unrelated to proportion of immigrants, $r(176)=.06, p=.46$, it was negatively related to conservative climate, $r(176)=-.38, p<.001$. As for the other contextual variables, standardized residuals excluding outlier values were used as predictors.
} 
In order to account for potential differences between linguistic regions in Switzerland, additional models with the original contextual variables (i.e., not the residual scores) and linguistic region as predictor $(0=$ German; $1=$ French $)$ were tested. This additional step allows us to confirm that the revealed effects were not due to differences between linguistic regions. While linguistic region had no impact on opposition to antiracism laws $(b=-1.03, p=.68)$, it significantly predicted intergroup contact $(b=0.18, p=.001)$ and perceived threat $(b=-7.39, p<.001)$. Respondents reported more contact with immigrants and less perceived threat in the French-speaking region (Contact: $M=1.27$, $S D=0.80$; Threat: $M=42.59, S D=16.28$ ) than in the German-speaking region (Contact: $M=0.94$, $S D=0.70$; Threat: $M=52.37 ; S D=13.14$ ). Linguistic region did not interact with proportion of immigrants or conservative ideological climate for neither perceived threat nor opposition to antiracism laws, while the linguistic region $\mathrm{x}$ proportion of immigrants interaction was marginally significant for intergroup contact $(b=0.82, p=.07)$. Simple slope analyses for this additional interaction showed that proportion of immigrants was more strongly related to intergroup contact in the French-speaking region $(b=14.27, p<.001)$ than in the German-speaking region $(b=0.45$, $p=.09)$. Importantly, the final model for contact yielded similar contextual effects as reported previously. In the case of perceived threat, while the other contextual measures did not explain any municipality-level variance, introducing linguistic region as a municipality-level predictor explained $44.07 \%$ of contextual variance (in addition to the $40.74 \%$ already explained in Model 2, Table 2). The multigroup confirmatory factor analysis presented in the method section suggests that this finding was not due to regional differences in the measurement of perceived threat. As a final verification, we also conducted separate analyses within each linguistic region. In the Germanspeaking region, effects were identical to those with the overall sample, with the exception of the positive relation between proportion of immigrants and intergroup contact which no longer reached significance $(b=0.00, p=.14$; though the impact of proportion of immigrants was significant when entered without climate in the model, $b=0.01, p=.006)$. In the French-speaking region, the relationship between conservative climate and opposition to antiracism laws was not significant.

\section{Discussion}

The present study examined individual and contextual predictors of opposition to antiracism laws across Swiss municipalities. We showed that the conservative ideological climate of a municipality was related to opposition to antiracism laws, over and above individual-level factors. A conservative climate also reduced intergroup contact in municipalities with a low proportion of immigrants. By introducing ideological climate as a novel contextual predictor for within-country studies, this research advances multilevel research on immigration attitudes that has up to now mainly examined the effects of structural features at the country level (Ceobanu \& Escandell, 2010). Our findings on conservative climate remained stable even when accounting for the proportion of immigrants and the economic status of municipalities. In addition, indirect effects were revealed: On both the individual and the municipality level, intergroup contact reduced threat perceptions of immigrants, which decreased opposition to antiracism laws. The proportion of immigrants in a municipality increased intergroup contact which in turn reduced perceived threat. In the following, the implications of these findings are discussed.

\section{Interplay between Ideological Climate and Proportion of Immigrants}

The revealed stronger opposition to antiracism laws in conservative municipalities is in line with prior survey research showing that the presence of radical right-wing political parties increases prejudice (Semyonov et al., 2006, 2007; Wilkes et al., 2007). As an alternative to the presence of right-wing parties, we used a measure based on a decade of Swiss referenda results as an indicator 
of conservatism of municipalities. Based on a social representations approach, we argued that the ideological climate is made up by shared normative stances that implicitly or explicitly guide reactions towards immigration. Importantly, we demonstrated that prevailing ideologies influenced opposition to antiracism laws in a municipality, over and above individuals' personal situation (i.e., income, age), personal ideologies (political orientation), and well-known antecedents of prejudice (contact and perceived threat) as well as the structural features of municipalities. The findings thus emphasize the importance of shared, normative understandings in explaining political attitudes.

In line with contact theory, reported intergroup friendships were more numerous in municipalities with a strong presence of immigrants, and this effect indirectly-though marginally-reduced perceived threat. This result supports the suggestion that the presence of immigrants at a local rather than national level is associated with prejudice reduction (see Schmid et al., 2008; Semyonov \& Glikman, 2009; Wagner et al., 2006). The revealed interaction between ideological climate and the presence of immigrants on intergroup contact sheds further light on the importance of shared ideologies on reactions toward immigrants. Indeed, the lowest levels of intergroup contact were found in conservative municipalities with a low immigrant proportion, whereas in municipalities with a high immigrant proportion conservative climate was unrelated to intergroup contact. This result indicates that contextual norms do not exist in a vacuum, but are influenced by the structural reality of societies. In municipalities with a strong presence of immigrants, the discrepancy between prevailing norms (e.g., in a conservative climate: "immigration is threatening") and the reality (i.e., "there are many immigrants, but they are not so threatening") may reduce the power of the normative climate. In contexts with fewer immigrants the normative climate has a greater impact.

In line with our expectations, the proportion of immigrants in a municipality did not affect opposition to antiracism laws and perceived threat directly. However, such links may have emerged if different measures had been used. First, prior studies have demonstrated that the perceived size of immigrant proportion can play a greater role than the actual immigrant proportion (see Schlueter \& Wagner, 2008; Semyonov, Raijman, Yom-Tov, \& Schmidt, 2004). Thus, individuals living in conservative municipalities may overestimate the proportion of immigrants in their municipality, which, in turn, would lead to higher levels of perceived threat. This could not be tested as the ESS questionnaire assessed the estimated percentage of immigrants in a country, but not in municipalities. Second, reactions may also depend on the types of immigrants people are exposed to and meet in their everyday lives (e.g., Green, Fasel, \& Sarrasin, 2010; Helbling, 2011; Schneider, 2008). On the one hand, immigrants considered as "culturally distant" and devalued (e.g., non-European or Muslim immigrants) are perceived as more threatening than "culturally close" and valued immigrants (e.g., Western European immigrants). On the other hand, immigrants competing with the national ingroup (e.g., Germans in the German-speaking region of Switzerland; Helbling, 2011) can also trigger negative immigration attitudes. Further investigation is needed to examine the links between ideological climate and types of immigrants. In conservative municipalities, the presence of immigrant groups perceived as threatening (either symbolically, because of cultural distance, or economically, because of competition for scarce resources) may trigger particularly negative reactions toward immigrants.

Contrary to our expectations, a conservative ideological climate was not directly related to higher levels of perceived threat. A specificity of the Swiss context, namely the cultural and political differences between linguistic regions, may explain this finding. As both perceived threat and conservatism were higher in the German-speaking region than in the French-speaking region, the absence of the link between these concepts can result from the use of residual scores (from which the difference between linguistic regions was eliminated) as contextual predictors. Accordingly, when linguistic region was not accounted for, conservatism was indeed significantly related to higher levels of perceived threat $(b=0.18, p=.003)$. Taken together, these findings highlight the importance of examining such within-country differences of immigration attitudes. 
Finally, we did not find evidence that in progressive climates with supposedly a greater tolerance for diverging attitudes, anti-immigrant attitudes would be related more strongly to individual political stances than in conservative climates (i.e., no cross-level interactions were found). In the current research, diverging ideological climates had comparable effects on individual-level relationships. However, more research is needed to further examine the impact of consensus within conservative versus progressive ideological climates.

\section{Understanding Within-Country Differences}

Investigating immigration attitudes across Swiss municipalities revealed the need to account for the multicultural and multilinguistic nature of the country. The greater perceived threat in the German-speaking over the French-speaking region confirms a cleavage frequently observed in immigration-related referendum results. This result is also in line with the assumption that national majorities feel more strongly attached to the nation than national minorities which may lead majorities to insist more on boundaries between the national ingroup and immigrant outgroups (e.g., Staerklé, Sidanius, Green, \& Molina, 2010; Sidanius, Feshbach, Levin, \& Pratto, 1997). Indeed national attachment has also been found to be higher in the German-speaking majority than in the French-speaking minority region (Green, Sarrasin, Fasel, \& Staerklé, 2011). The results of the current study show that when studying immigration attitudes in a country with distinct linguistic or cultural regions or when such countries are included in cross-national comparisons, the asymmetry between those regions needs to be considered (see also Billiet, 2003, on immigration attitudes of Walloons and Flemish in Belgium).

The choice of unit of analysis is another aspect of within-country studies that requires consideration. Supporting other recent research (Hjerm, 2009; Lubbers et al., 2006; Schlueter \& Scheepers, 2010; Wagner et al., 2006), our results showed that contextual features play a role on immigration attitudes at a proximal, municipality level. Because Switzerland is composed of 26 cantons (in which municipalities are nested), a canton-level analysis could have been an alternative. Municipalities were nevertheless chosen over cantons because we focused on effects of a shared ideological climate. To the extent that the ideological climates differ considerably across municipalities within the same canton (Leuthold et al., 2007), the use of the most proximal unit of analysis—-the municipality-was warranted. However, were the focus on the impact of legislation on immigration attitudes for example, the canton-level may have been the more appropriate unit as legislation is often implemented on this level.

\section{Conceptualization of Intergroup Contact and Ideological Climate}

The conceptualization and operationalization of intergroup contact and ideological climate in the current research also require further thought. First, in line with previous research, our results showed, albeit only on the individual level, that intergroup contact - tapped with quantity of intergroup friendships-reduced threat perceptions of immigrants, which in turn decreased opposition to antiracism laws. Though correlational data do not allow definite causal conclusions, existing empirical evidence suggests that contact has a stronger impact on prejudice than vice versa (e.g., Wagner et al., 2003). We are therefore fairly confident of the revealed mediation pattern. However, contrary to some studies (e.g., McLaren, 2003; Schmid et al., 2008), intergroup contact did not directly reduce prejudice. Tausch, Tam, Hewstone, Kenworthy, and Cairns (2007) proposed that the conceptualization of contact might explain why in some cases intergroup contact only indirectly reduced negative reactions toward immigrants. In their study the relation between quality of contact and outgroup attitudes was indirect, mediated by perceived threat and intergroup anxiety, while the link between quantity of contact and outgroup attitudes was direct. The common affective component of good- 
quality relations and fear (feelings of threat, anxiety) may also explain our results. Thus the fact that we assessed contact through the reported number of intergroup friendships (which can be assumed to indicate high quality contact) would explain why the decrease in opposition to antiracism laws operates only through a decrease in perceived threat.

Second, the measure of ideological climate used in the present study tapped the degree of conservatism within a municipality, but not the range of political stances within this climate: Municipalities located midway on the progressive-conservative continuum may include residents with strongly polarized opinions or they may include a population endorsing more or less similar ideological stances. From a social representations perspective (Moscovici, 2000; see also Glaveanu, 2009), in municipalities hosting a greater attitudinal diversity, the opinions of its members should be less tainted by the climate, because they are aware of a wider range of possible attitudes and have a greater freedom of expressing their views. Thus future research should account not only for the level of conservative climate, but also for the dispersion, or range, of prevailing ideologies.

\section{Conclusion}

We demonstrated that the ideological climate within a municipality influences citizens' reactions towards immigrants, over and above individual characteristics. The results call for the inclusion of normative factors of social contexts in multilevel research on immigration attitudes. Though adopting antiracism laws on the institutional level can be considered an important first step for the reduction of anti-immigrant prejudice and discrimination, to be truly effective, the premises of such laws need to be integrated in individuals' value systems. The findings of this research thus imply that institutional efforts, for example by means of antiracism campaigns, should especially promote positive intergroup contacts and put into perspective threat-evoking topics such as alleged cultural differences or labor market issues. Such efforts may ultimately render the ideological climate more progressive and tolerant.

\section{ACKNOWLEDGMENTS}

This work was supported by the Swiss National Science Foundation (100014_122407). Correspondence concerning this article should be sent to Oriane Sarrasin or Eva G. T. Green, Institute for Social Sciences, Faculty of Social and Political Sciences, University of Lausanne, CH-1015 Lausanne, Switzerland. E-mail: oriane.sarrasin@unil.ch or eva.green@unil.ch. The first two authors contributed equally to this article.

\section{REFERENCES}

Allport, G. W. (1954). The nature of prejudice. Reading, MA: Addison-Wesley.

Bar-Tal, D. (2000). Shared beliefs in a society: Social psychological analysis. Thousand Oaks, CA: Sage.

Billiet, J. (2003). Cross-cultural equivalence with structural equation modeling. In J. A. Harkness, F. J. R. Van de Vijver, \& P. P. Mohler (Eds.), Cross-cultural survey methods (pp. 247-264). New York: John Wiley.

Blalock, H. M. (1967). Toward a theory of minority-group relations. New York: Capricorn Books.

Bornschier, S. (2010). Integrating the defence of traditional communities into the libertarian-authoritarian divide: The role of the Swiss People's Party in the redefinition of cultural conflicts. In S. Hug \& H. Kriesi (Eds.), Value change in Switzerland (pp. 121-141). Lanham, MD: Lexington Books.

Brown, R., \& Hewstone, M. (2005). An integrative theory of intergroup contact. In M. Zanna (Ed.), Advances in experimental social psychology (Vol. 37, pp. 255-343). San Diego, CA: Academic Press.

Ceobanu, A. M., \& Escandell, X. (2010). Comparative analyses of public attitudes toward immigrants and immigration using multinational survey data: A review of theories and research. Annual Review of Sociology, 36, 309-328.

Chryssochoou, X. (2004). Cultural diversity: Its social psychology. Oxford: Blackwell. 
Clémence, A. (2001). Social positioning and social representations. In K. Deaux \& G. Philogène (Eds.), Representations of the social: Bridging theoretical traditions (pp. 83-95). Oxford: Blackwell.

Cornelis, I., Van Hiel, A., Roets, A., \& Kossowska, M. (2009). Age differences in conservatism: Evidence on the mediating effects of personality and cognitive style. Journal of Personality, 77, 51-88.

Dandy, J., \& Pe-Pua, R. (2010). Attitudes to multiculturalism, immigration and cultural diversity: Comparison of dominant and non-dominant groups in three Australian states. International Journal of Intercultural Relations, 34, 34-46.

Dardanelli, P. (2008). Debate: Communicative nation and multi-nationalism multi-national Switzerland? A comment on Ipperciel. Swiss Political Science Review, 14, 551-561.

Davidov, E., Meuleman, B., Billiet, J., \& Schmidt, P. (2008). Values and support for immigration: A cross-country comparison. European Sociological Review, 24, 583-599.

Doise, W., Clémence, A., \& Lorenzi-Cioldi, F. (1993). The quantitative analysis of social representations. London: Harvester Wheatsheaf.

Elcheroth, G., Doise, W., \& Reicher, S. (2011). On the knowledge of politics and the politics of knowledge: How a social representations approach helps us rethink the subject of political psychology. Political Psychology, 32, 729758.

Espenshade, T. J., \& Calhoun, C. A. (1993). An analysis of public opinion toward undocumented immigration. Population Research and Policy Review, 12, 189-224.

Esses, V. M., Jackson, L. M., Dovidio, J. F., \& Hodson, G. (2005). Instrumental relations among groups: Group competition, conflict and prejudice. In J. F. Dovidio, P. Glick, \& L. A. Rudman (Eds.), On the nature of prejudice: Fifty years after Allport (pp. 227-243). Oxford: Blackwell.

European Commission against Racism and Intolerance (ECRI) (2009). Statement by the European Commission against Racism and Intolerance on the ban of the construction of minarets in Switzerland. Retrieved from http://www.coe.int/ t/dghl/monitoring/ecri/activities/35-Declaration_minarets/Declaration_en.asp

Falomir-Pichastor, J. M., Muñoz-Rojas, D., Invernizzi, F., \& Mugny, G. (2004). Perceived in-group threat as a factor moderating the influence of in-group norms on discrimination against foreigners. European Journal of Social Psychology, 34, 135-153.

Federal Department of Justice and Police (2007). Hearing concernant la norme pénale sur le racisme [Hearing on the penal norm against racism]. Retrieved from http://www.ejpd.admin.ch/ejpd/fr/home/dokumentation/mi/2007-05-23.html

Federal Statistical Office (2010a). Le paysage linguistique en Suisse [The linguistic landscape in Switzerland]. Retrieved from http://www.bfs.admin.ch/bfs/portal/fr/index/themen/01/22/publ.html?publicationID=1738

Federal Statistical Office (2010b). Revenus et dépenses de l'ensemble des ménages [Household income and expenses]. Retrieved from http://www.bfs.admin.ch/bfs/portal/fr/index/themen/20/02/blank/key/einkommen0/niveau.html

Federal Statistical Office (2010c). Population résidante étrangère [Foreign resident population]. Retrieved from: http://www. bfs.admin.ch/bfs/portal/fr/index/infothek/lexikon/bienvenue__login/blank/zugang_lexikon.Document.67228.xls

Federal Statistical Office (2010d). Disparités socioculturelles: les 4 indices [Sociocultural disparities: the 4 indices]. Retrieved from: http://www.bfs.admin.ch/bfs/portal/de/index/regionen/03/dos/gesellschaft_und_kultur/02.html

Gelman, A., \& Hill, J. (2007). Data analysis using regression and multilevel/hierarchical models. New York: Cambridge University Press.

Glaveanu, V.-P. (2009). What differences make a difference? A discussion of hegemony, resistance and representation. Papers on Social Representations, 18, 2.1-2.22.

Green, E. G. T. (2009). Who can enter? A multilevel analysis on public support for immigration criteria across 20 European countries. Group Processes \& Intergroup Relations, 12, 41-60.

Green, E. G. T., Fasel, N., \& Sarrasin, O. (2010). The more the merrier? The effects of type of diversity on immigration attitudes in Switzerland. International Journal of Conflict and Violence, 4, 177-190.

Green, E. G. T., Sarrasin, O., Fasel, N., \& Staerklé, C. (2011). Nationalism and patriotism as predictors of immigration attitudes in Switzerland: A municipality-level analysis. Swiss Political Science Review, 17, 369-393.

Helbling, M. (2009). Citizenship, right-wing populism and the direct democratic dilemma. In M. A. Niggli (Ed.), Right-wing extremism in Switzerland-National and international perspectives (pp. 102-112). Baden-Baden, Germany: Nomo.

Helbling, M. (2010). Islamophobia in Switzerland: A new phenomenon or a new name for xenophobia. In S. Hug \& H. Kriesi (Eds.), Value change in Switzerland (pp. 65-80). Lanham, MD: Lexington Books.

Helbling, M. (2011). Why Swiss-Germans dislike Germans. European Societies, 13, 5-27.

Hermann, M. (2006). Werte, Wandel und Raum. Theoretische Grundlage und empirische Evidenzen zum Wandel regionaler Mentalitäten in der Schweiz [Values, change and space: Theoretical bases and empirical evidence of change in regional mentalities in Switzerland]. Zurich: University of Zurich. 
Hjerm, M. (2009). Anti-immigrant attitudes and cross-municipal variation in the proportion of immigrants. Acta Sociologica, $52,47-62$.

Horber-Papazian, K. (2007). The municipalities. In W. Linder, Y. Papadopoulos, H. Kriesi, P. Knoepfel, U. Klöti, \& P. Sciarini (Eds.), Handbook of Swiss Politics (pp. 227-252). Zurich: NZZ Publishing.

Hox, J. (2010). Multilevel analysis: Techniques and applications. New York: Routledge.

Islam, M. R., \& Hewstone, M. (1993). Dimensions of contact as predictors of intergroup anxiety, perceived outgroup variability, and outgroup attitudes: An integrative model. Personality and Social Psychology Bulletin, 19, 700710.

Joffe, H., \& Staerklé, C. (2007). The centrality of the self-control ethos in Western aspersions regarding outgroups: A social representational analysis of common stereotype content. Culture and Psychology, 13, 395-418.

Jost, J. T., Glaser, J., Kruglanski, A.W., \& Sulloway, F. (2003). Political conservatism as motivated social cognition. Psychological Bulletin, 129, 339-375.

Jost, J. T., Krochik, M., Gaucher, D., \& Hennes, E. P. (2009). Can a political theory of ideological differences explain contextual variability in the contents of political attitudes? Psychological Inquiry, 20, 183-188.

Jost, J. T., Ledgerwood, A., \& Hardin, C. D. (2008). Shared reality, system justification, and the relational basis of ideological beliefs. Social and Personality Psychology Compass, 2, 171-186.

Kreft, I., \& de Leeuw, J. (1998). Introducing multilevel modeling. London: Sage.

Kriesi, H., Wernli, B., Sciarini, P., \& Gianni, M. (1996). Le clivage linguistique. Problèmes de compréhension entre les communautés linguistiques en Suisse [The linguistic cleavage: Comprehension difficulties between the Swiss linguistic communities]. Bern, Switzerland: Federal Statistical Office.

Krull, J. L., \& MacKinnon, D. P. (2001). Multilevel modeling of individual and group level mediated effects. Multivariate Behavioral Research, 36, 249-277.

Kuhn, J.-T., \& Holling, H. (2009). Gender, reasoning ability, and scholastic achievement: A multilevel mediation analysis. Learning and Individual Differences, 19, 229-233.

Lahav, G. (1997). Ideological and party constraints on immigration attitudes in Europe. Journal of Common Market Studies, $35,377-406$.

Lahav, G. (2004). Immigration and politics in the new Europe. Cambridge: Cambridge University Press.

Leuthold, H., Hermann, M., \& Fabrikant, S. I. (2007). Making the political landscape visible: mapping and analyzing voting patterns in an ideological space. Environment and Planning B: Planning and Design, 34, 785-807.

Lorenzi-Cioldi, F., \& Clémence, A. (2001). Group processes and the construction of social representations. In M. Hogg \& R. Tindale (Eds.), Blackwell handbook in social psychology, Vol. 3: Group processes (pp. 311-333). Oxford: Blackwell.

Lubbers, M., Coenders, M., \& Scheepers, P. (2006). Objections to asylum seeker centres: Individual and contextual determinants of resistance to small and large centres in the Netherlands. European Sociological Review, 22, $243-257$.

Lubbers, M., Gijsberts, M., \& Scheepers, P. (2002). Extreme right-wing voting in Western Europe. European Journal of Political Research, 41, 345-378.

Lüdtke, O., Marsh, H. W., Robitzsch, A., Trautwein, U., Asparouhov, T., \& Muthén, B. (2008). The multilevel latent covariate model: A new, more reliable approach to group-level effects in contextual studies. Psychological Methods, 13, $203-229$.

Luo, X., Rindfleisch, A., \& Tse, D. K. (2007). Working with rivals: The impact of competitor alliances on financial performance. Journal of Marketing Research, 44, 73-83.

Maas, C. J. M., \& Hox, J. J. (2005). Sufficient sample sizes for multilevel modeling. Methodology, 1, 86-92.

Masso, A. (2009). A readiness to accept immigrants in Europe? Individual and country-level characteristics. Journal of Ethnic and Migration Studies, 35, 251-270.

McLaren, L. M. (2003). Anti-immigrant prejudice in Europe: Contact, threat perception, and preferences for the exclusion of migrants. Social Forces, 81, 909-936.

Meuleman, B. (2010). Perceived economic threat and anti-immigration attitudes: Effects of immigrant group size and economic conditions revisited. In E. Davidov, P. Schmidt, \& J. Billiet (Eds.), Cross-cultural methods and applications (pp. 283-312). New York: Routledge.

Miller, N. (2002). Personalization and the promise of contact theory. Journal of Social Issues, 58, 387-410.

Moscovici, S. (2000). Social representations: Explorations in social psychology. Cambridge: Polity Press.

Nicolet, S., \& Sciarini, P. (2006). When do issue opinions matter, and to whom? The determinants of long-term stability and change in party choice in the 2003 Swiss elections. Swiss Political Science Review, 12, 159-190.

Oliver, J. E., \& Wong, J. (2003). Intergroup prejudice in multiethnic settings. American Journal of Political Science, 47, $567-582$.

Pettigrew, T. F. (1958). Personality and sociocultural factors in intergroup attitudes: A cross-national comparison. Journal of Conflict Resolution, 2, 29-42. 
Pettigrew, T. F. (1997). Generalized intergroup contact effects on prejudice. Personality and Social Psychology Bulletin, 23, $173-185$.

Pettigrew, T. F. (1998). Intergroup contact theory. Annual Review of Psychology, 49, 65-85.

Pettigrew, T. F., \& Tropp, L. R. (2006). A meta-analytic test of intergroup contact theory. Journal of Personality and Social Psychology, 90, 751-783.

Philogène, G., \& Deaux, K. (2001). Introduction. In K. Deaux \& G. Philogène (Eds.), Representations of the social: Bridging theoretical traditions (pp. 3-7). Oxford: Blackwell.

Preacher, K. J., Curran, P. J., \& Bauer, D. J. (2006). Computational tools for probing interaction effects in multiple linear regression, multilevel modeling, and latent curve analysis. Journal of Educational and Behavioral Statistics, 31, 437-448.

Preacher, K. J., Zyphur, M. J., \& Zhang, Z. (2010). A general multilevel SEM framework for assessing multilevel mediation. Psychological Methods, 15, 209-233.

Quillian, L. (1995). Prejudice as a response to perceived group threat: Population composition and anti-immigrant and racial prejudice in Europe. American Sociological Review, 60, 586-611.

Riek, B. M., Mania, E. W., \& Gaertner, S. L. (2006). Intergroup threat and outgroup attitudes: A meta-analytic review. Personality and Social Psychology Review, 10, 336-353.

Royston, P. (2005). Multiple imputation of missing values: Update. The Stata Journal, 5, 188-201.

Scheepers, P., Gijsberts, M., \& Coenders, M. (2002). Ethnic exclusion in European countries: Public opposition to civil rights for legal migrants as a response to perceived ethnic threat. European Sociological Review, 18, 17-34.

Schlueter, E., \& Scheepers, P. (2010). The relationship between outgroup size and anti-outgroup attitudes: A theoretical synthesis and empirical test of group threat- and intergroup contact theory. Social Science Research, 39, $285-295$.

Schlueter, E., \& Wagner, U. (2008). Regional differences matter: Examining the dual influence of the regional size of the immigrant population on derogation of immigrants in Europe. International Journal of Comparative Sociology, 49, $153-173$.

Schmid, K., Tausch, N., Hewstone, M., Hughes, J., \& Cairns, E. (2008). The effects of living in segregated vs. mixed areas in Northern Ireland: A simultaneous analysis of contact and threat effects in the context of micro-level neighbourhoods. International Journal of Conflict and Violence, 2, 56-71.

Schneider, S. L. (2008). Anti-immigrant attitudes in Europe: Outgroup size and perceived ethnic threat. European Sociological Review, 24, 53-67.

Sciarini, P., \& Tresch, A. (2009). A two-level analysis of the determinants of direct democratic choices in European, immigration and foreign policy in Switzerland. European Union Politics, 10, 456-481.

Sears, D. O., \& Henry, P. J. (2003). The origins of symbolic racism. Journal of Personality and Social Psychology, 85, 259-275.

Semyonov, M., \& Glikman, A. (2009). Ethnic residential segregation, social contacts, and anti-minority attitudes in European societies. European Sociological Review, 25, 693-708.

Semyonov, M., Raijman, R., \& Gorodzeisky, A. (2006). The rise of anti-foreigner sentiment in European societies, 19882000. American Sociological Review, 71, 426-449.

Semyonov, M., Raijman, R., \& Gorodzeisky, A. (2007). On the relations between right-wing parties and anti-foreigner sentiment. A reply to Wilkes, Guppy, and Farris. American Sociological Review, 72, 841-849.

Semyonov, M., Raijman, R., Yom-Tov, A., \& Schmidt, P. (2004). Population size, perceived threat, and exclusion: A multiple-indicators analysis of attitudes toward foreigners in Germany. Social Science Research, 33, 681-701.

Sidanius, J., Feshbach, S., Levin, S., \& Pratto, F. (1997). The interface between ethnic and national attachment: Ethnic pluralism or ethnic dominance? Public Opinion Quarterly, 61, 102-133.

Sidanius, J., \& Pratto, F. (1999). Social dominance: An intergroup theory of social hierarchy and oppression. New York: Cambridge University Press.

Sides, J., \& Citrin, J. (2007). European opinion about immigration: The role of identities, interests and information. British Journal of Political Science, 37, 477-504.

Sniderman, P. M., Hagendoorn, L., \& Prior, M. (2004). Predisposing factors and situational triggers: Exclusionary reactions to immigrant minorities. American Political Science Review, 98, 35-49.

Spini, D., \& Doise W. (2005). Human rights and duties as normative social representations. In N. J. Finkel \& F. Moghaddam (Eds.), The psychology of human rights and duties: Empirical contributions and normative comments (pp. 21-48). Washington, DC: American Psychological Association.

Staerklé, C. (2009). Policy attitudes, ideological values and social representations. Social and Personality Psychology Compass, 3, 1069-1112.

Staerklé, C., Clémence, A., \& Spini, D. (2011). Social representations: A normative and dynamic intergroup approach. Political Psychology, 32, 759-768. 
Staerklé, C., Sidanius, J., Green, E. G. T., \& Molina, L. (2010). Ethnic minority-majority asymmetry in national attitudes around the world: A multilevel analysis. Political Psychology, 31, 491-519.

Steenkamp, J.-B. E. M., \& Baumgartner, H. (1998). Assessing measurement invariance in cross-national consumer research. Journal of Consumer Research, 25, 78-90.

Stephan, W. G., \& Renfro, C. L. (2003). The role of threat in intergroup relations. In D. M. Mackie \& E. R. Smith (Eds.), From prejudice to intergroup emotions: Differentiated reactions to social groups (pp. 191-207). New York: Psychology Press.

Tausch, N., Tam, T., Hewstone, M., Kenworthy, J., \& Cairns, E. (2007). Individual-level and group-level mediators of contact effects in Northern Ireland: The moderating role of social identification. British Journal of Social Psychology, 46, 541-556.

Thorisdottir, H., Jost, J. T., Liviatan, I., \& Shrout, P. E. (2007). Psychological needs and values underlying left-right political orientation: Cross-national evidence from Eastern and Western Europe. Public Opinion Quarterly, 71, $175-203$.

Trechsel, A. H. (2007). Popular votes. In U. Klöti, P. Knoepfel, H. Kriesi, W. Linder, Y. Papadopoulos, \& P. Sciarini (Eds.), Handbook of Swiss politics (pp. 435-461). Zurich: NZZ Publishing.

Turner, R. N., Hewstone, M., \& Voci, A. (2007). Reducing explicit and implicit prejudice via direct and extended contact: The mediating role of self-disclosure and intergroup anxiety. Journal of Personality and Social Psychology, 93, 369-388.

Turner, R. N., Hewstone, M., Voci, A., Paolini, S., \& Christ, O. (2007). Reducing prejudice via direct and extended cross-group friendship. European Review of Social Psychology, 18, 212-255.

Van de Vijver, F. J. R., Van Hemert, D. A., \& Poortinga, Y. H. (2008). Conceptual issues in multilevel models. In F. J. R. Van de Vijver, D. A. Van Hemert, \& Y. H. Poortinga (Eds.), Multilevel analysis of individuals and cultures (pp. 3-26). New York: Erlbaum.

Wagner, U., Christ, O., Pettigrew, T. F., Stellmacher, J., \& Wolf, C. (2006). Prejudice and minority proportion: Contact instead of threat effects. Social Psychology Quarterly, 69, 380-390.

Wagner, U., van Dick, R., Pettigrew, T. F., \& Christ, O. (2003). Ethnic prejudice in East and West Germany: The explanatory power of intergroup contact. Group Processes \& Intergroup Relations, 6, 22-36.

Wheaton, B., Muthén, B., Alwin, D. F., \& Summers, G. (1977). Assessing reliability and stability in panel models. Sociological Methodology, 8, 84-136.

Wilkes, R., \& Corrigall-Brown, C. (2011). Explaining time trends in public opinion: Attitudes towards immigration and immigrants. International Journal of Comparative Sociology, 52, 79-99.

Wilkes, R., Guppy, N., \& Farris, L. (2007). Right-wing parties and anti-foreigner sentiment in Europe. Comment on Semyonov, Raijman and Gorodzeisky. American Sociological Review, 72, 831-840. 